\title{
ORIGINS OF FORMATION OF SOCIAL INNOVATION IN TRANSITION ECONOMY
}

\author{
Olha BILSKAYA', \\ Oles Honchar Dnipropetrovsk National University, Ukraine
}

\begin{abstract}
Purpose of the work is determination of the essence, source base and mechanism of formation of "social innovation" under the conditions of the transitional economy with a market mechanism for ensuring activity in the territory of countries, engaged in the development of a social state. Methodology. To solve this problem, a number of scientific methods was used, such as analysis and synthesis during the critical evaluation of approaches of domestic and foreign authors regarding the nature of "novation", "developments" and "innovation", system and structural in the design of the mechanism of cyclic renewal of the institutional content of the regulation system of social development, summarizing in justifying the conceptual terminological apparatus of social innovation, and in particular gradual clarification of the social innovation formulas, abstract and logic when making theoretical generalizations and forming conclusions. Results of the study lead to the need of introducing the term "social" in the scientific and practical use, as normalized inequality in the society to the limits that define the motivational aspects of work, and "innovation" as changes that are generated within the social and economic system. Social innovations were proposed to be interpreted as solutions that can change directly or indirectly selectively fixed institutions in different sectors of the national economy of the country at the appropriate stage of the socialization transformations with compulsory positivization of the social status of subjects of social and economic processes through constructs of mitigation of the revenue and income inequality. It has been proved that the source base of the social innovation is social traditions, which by virtue of multi-purpose certainty are associated with metamorphic feature and stochasticity of a set of proposals of social innovations and their destructive constructs. Practical implications. Organization of the conceptual and categorical apparatus of the social innovation will promote to justification of social policy measures and will exclude from the practice of managing the situation regarding a non-professional solution of problems of ensuring public progress. Value/originality. The scientific and practical significance of developments means that they provide a basis for theoretical and methodological justification of processes of social innovation, and should change for the better and welfare.
\end{abstract}

Key words: social innovation, concepts, approaches, destruction, formation mechanism, and concept.

JEL Classification: R14, O31, J24

\section{Introduction}

The driving force of economic development of the world community for centuries was and is innovations. However, in the full extent the innovation processes, despite a long history, have been the subject of scientific study only in the XX century. And, what is the most important, so it was the identification of innovation solely with technical and technological changes first in the industry, and then in other areas of economic activity. In the last decade of the XX century and largely with transition to the coordinate system of the XXI century in the industrialized countries, practically all spheres of human activity were gradually covered by innovations. But over time it became increasingly clear that the only technical innovation is not enough to overcome the challenges of the modern society.
For the establishment of the institute of the welfare state, which is built in the territory of Ukraine and its effective functioning, we need a fundamentally new type of innovations that are able to create changes not only in the economic sphere but also in the social sphere, and thereby contribute to the formation of the civilization quality of the life of a decent person. They are called social innovations.

It should be emphasized that the issues of social innovation due to the reorientation of the national economy on an innovative path of development have become one of the main topics of problem and oriented research. But in general, "social innovation" and "social innovation processes" as the main content of the innovative model of ensuring the social progress are not new categories for the science.

\footnotetext{
Corresponding author

${ }^{1}$ Department of Economics and Management of National Economy, Oles Honchar Dnipropetrovsk National University.

E-mail: lexusol@yandex.ru
} 
The analysis of the literature sources of the raised issue gives an opportunity to state the compilation of several scientific currents on the interpretation of social innovation direction. This is natural as economists, sociologists, philosophers, psychologists, teachers, lawyers and politicians were involved and engaged in the development of this problem. At the same time some of them were interested and are interested in short-term one-way processes, and others - in long-term and multivector transformation. Moreover, theoretical development of specific fields of science by the experts would seem to frame the issue, carried out by them in different time intervals for restructuring the social state and the territory of different countries.

Innovation Theoretical Foundations in the social sphere were offered by the Russian-American sociologist P. Sorokin. It is natural that his achievements have been supplemented and developed by scientists of the developed countries in the context of the constitutional declaration of the social states after the Second World War. It is about A. Giddens, P. David, D. Foreyya, S. Courtois, J. Nesbitt, K. Polanyi and others. But the results of their scientific thoughts were implemented to the classical type of formation first of the market economy, and then its immunization of the one or other dose of sociality. In postSoviet time the development of the concept of a social state is carried out by something opposite, inversion principle with some backsliding on large-scale socialization through the state financing. In the context of such specificity among national scientists a number of representatives who initiated research on the social innovation also started to be separated, such as L. Antoniuk, L. Boyko-Boychuk, E. Kuchko, N. Letunovska, I. Meyzhys A. Poruchnyk, B. Savchuk, A. Sandyha, L. Fedulova, and others.

But knowledge was and remains a relative category. So the fact of holding some interpretations of social innovations of theoretical and methodological differences is natural. In addition, a reasoned decision as to the source base of social innovations has not been discovered until recently. As a result, not the whole set of processes and phenomena that make up the essence of the social are subject under the direct influence of the state. Moreover, the innovation social programs, taken for implementation at different levels of management, turn out to be incapable by their potencies of influence to adequately respond to the made destructive aspects in ensuring social dynamics. These realities certify in favor of the fact that the issue of implementation of its social purpose by the state through social innovation is as complex organization, some of them require further research in the context of streamlining the content of the mechanism of formation and technology implementation.

Guided by urgent requirement to strengthen the social component in ensuring social dynamics, within this article we have put a research problem, whose main task is the certainty with essence, source base and mechanism of formation of "social innovation" in the transitional economy with a market mechanism for ensuring activity in the territory, engaged in the development of the social state. Basically the represented is seen as a replication and extension, but something borrowed and qualitative upgrading to review investigations (Azgaldov, G.G., \& Kostin, A.V. (2008); Cherepanova, N.V. (2007); Elias, N. (2001); Grishkin, V.O. (2005); Huchek, M. (1995); Perlaki, I. (1980); Zinoviev, A.A. (2008)).

\section{Concept of nature of social innovations}

The term "social innovation" is a phrase from the concepts of "social" and "innovation". Mostly the term "social" was identified and today is interpreted as "public".

In Soviet times the social research was narrowed to the extent caused by political expediency. Thus, in the "Dictionary of Russian language", the term "social" is defined as "public, referred to people's lives and their relations in the society" (Ozhegov, 1953) and in the political dictionary of the Soviet era the concept of "social" is associated exclusively with "attitude to the social order" (Ponomarev, 1956).

It is natural that with the deployment of democratization of public life and centrifugal processes that led to the declaration of independence of former Soviet republics in the late 90 s of the twentieth century, the issue of the nature of "social" has actualized. However the regulation of the term "social" has not changed dramatically.

Modern explanatory dictionary editions are virtually the same footsteps with no desire to build a theoretical apparatus of sociality adequate to the situation occurred in the country. As a social content they present all the same, namely, "... linked to the life and relations of people in the society, the public" (Yaremenko and Slipushko, 2001).

National experts of the sociological direction in the interpretation of the concept "social" reduce it to "... the attraction to another person against the will and desire of both or a combination of several of them in the community" (Andrushchenko and Gorlach, 1996) or "active communication between people" (Andrushchenko and Mihalchenko,1996, pp. 95-96). As for the views of economists about the nature of "social", they are reduced to either "... the system features, integrated effect of direct or indirect interaction between people" (Deeva, 2006) or the "... Possibilities of a decent life in the society” (Grishkin, 2005).

Thus, the formula of sociality has not received the final character and if left open for further philosophy regarding the nature of "life" and "relations in the society". Taking into account this fact, our understanding of the nature of "social" is not something that is not compounded, but do not get adequate time of a formal nature. As a result, we live in the linguistic world saturated with a term "social" in different meaningful combinations as relevant and irrelevant for it.

Indeed, you cannot find objections, because people in the process of life come into relations with each other. However, productive activities and meeting the needs of the economic entities are only possible in unity and mutual 
understanding. In reality, these attributes of social features are sufficiently contradictory. The given interpretation of the social aspect ignores these nuances of social relations. It seems that scientists fear unreliable social reality which forces to remain in positions of controversial decisions, adaptability to the situation, and so on.

A statement the German sociologist N. Elias (2001) regarding the issue of social concept, who identified it with "structural changes associated with the growth of differentiation and integration "and" aimed at reducing differentiation and integration, is correct in this context.

The present requires disclosure of the logic of the latest social and economic and social processes on axis "equalityinequality". And in this case it is extremely important to focus on the fact that the dominance of inequality within certain limits is not an abnormal phenomenon, and appears in the market economy as an integral part of social evolution.

A prominent dissident Russian scientist A.A. Zinoviev (2008) on this occasion said that "the paradox of history ... is that the tendency of inequality is more progressive and promising" and further "progress of inequality is the change of inequalities, which are improving the living conditions of the most active part of the society, and perhaps other members of the society". According to the statement of the modern intellectual K. Popper (2004) “... the desire for equality, particularly in the economic sphere can be a threat ...."

Based on these methodological definitions, we can state that the term "social" for economic transition should be associated with standardized inequality in the society to the limits that define the motivational aspects of the work. The starting point of its establishment is the generation of the awareness of initial needs and interests by the workers, who being objective by their nature influenced by comparison with the results of meeting the similar needs of other more active economic actors, are experienced as dissatisfaction with conditions of existence.

As for the term "innovation" it is necessary to take into account the fact that it consists of the concept "novation" and the prefix "in". Then there is a question of substantial difference of this category from "novation".

Some scientists regarding the prefix "in" refer to a translation in Latin as "in the direction" (Azgaldov and Kostin, 2008), and others, following the etymology of the term "in", give it a value of "internal" and "inside" (Cherepanova, 2007). If guided by the first one, the innovation does not differ from novation or developments, which are also understood as "... any purposeful, positive and progressive change ..." (Perlaki, 1980) or “... purposeful change that makes the environment ... introducing new elements relatively stable" (Prigogine, 1989, p. 29). Thus, "innovation" should be linked with the changes that are generated within the social and economic system.

In our opinion, adequate time would be appropriate at first to identify social innovation at the macro level with solutions that can change directly or indirectly, the social status of the subjects of social and economic processes at the appropriate stage of socialization reforms.
But we have to consider another as well. In the definition there is no focus on the source basis of the social innovation, and a very general approach is used, as a result of which it becomes universal, noting possible welfare increase from a weak reference to the realities of their generation.

\section{Sources of formation of social innovations}

The fact that the concept "innovation" was introduced in the scientific revolution in the XIX century at the suggestion of the famous Austrian economist J. Schumpeter (1982) is well-known. He understood by it "... a new quality or property of the means of production that can be obtained by improving the existing equipment". Further J. Schumpeter showed the specter of innovation with more details also covering other factors and areas of social and economic activities. But the main thing is not the essence and typology of innovation, and the nature of their occurrence defined by it. This separation requires more attention because it is of fundamental methodological load. In this context, the emphasis of the author to the phrase "improvement of existing" draws attention. It turns out that innovation cannot be just designed object. Innovation appears not as just created novation and qualitatively transformed, previously known as a sample. Everything that we attribute to the new, the majority borrows "construction material" of the previous system state. Considering this, in our view, the key statement for understanding the emergence of innovation methodology should emphasize that the people apply such a thing as tradition to display the past in the present and in the future.

It is not about an abstract concept, but rather a massive phenomenon and that covers all the elements of social coexistence and directly related to the emissions of innovation and developments and, moreover, formats them according to the essence and social role. A tradition acts as one of the most effective mechanisms of human communities' adaptation to the changing environment through regulation of norms and values. As a rule all changes in the agreed and existing community of people take place due to the reason of exhausting their possibilities of solving vital problems in ways that were used before. In the process of understanding the new reality, the society always deals with a certain amount of already identified states of the one or another state of the economy. This repetition is inherent in the most social and economic system. However, it cannot be considered as a repetition return back.

Involvement of the tradition in the processes of human activity unfolds in the form of a circle, which is essentially a "circle of circles" and finds explanation in bringing the tradition for functioning under the changed circumstances, to return back for identifying its braking elements and then move forward to adapt traditions through sub-functions in the already changed society. However, it is important to take into account the fact that the previous fixing traditions involved in the present serve as a source maintaining the dynamics of the directional process which continually brings social system to a desired 
state of the human community. So tradition involved in the process of social development, realizing the potential of streamlining processes in the social system ensures repeatability, predictability and accountability and, thereby, contributes to their inclusion in the area of social expediency. All the aforementioned confirms the fact that the tradition is not something static, because at each stage of its involvement in social development processes there are actions for improving implementation of mechanisms potentially inherent in it structural roots. It should be noted that the tradition is not opposed to change, but rather creates a spatial and temporal context, which updates the changes. The point is that due to the positive traditions of the previous stage of social development as stable invariant elements, values, relationships and social relations transferred to the present. And it is the presence of invariant, that is something unchanging that determines the stability of the social and economic system.

It turns out that by its nature a tradition and novation are inextricably linked. They mutually stipulate, complement and reinforce each other.

Guided by the given statements we can believe that due to the appointment of the tradition of the social plan there is a constant setting of the target vector of social dynamics by metamorphic way and stochasticity of a set of proposals to ensure innovation and thus the evolution of some persistent macro-states at the relevant stage of social dynamics. The expressed gives reason to believe that social tradition in contrast to all other content types is a relatively more complex phenomenon than a number of reasons. Social tradition is quite versatile. First of all, it includes many components. Secondly, it has integrative function, and its sub-functions stipulating it. Thirdly, it finds its expression in sufficient quantity of changing and unstable forms, methods, approaches, etc. Fourth, it is a landmark of innovation searches. Fifthly, the tradition of social content is a means of regulating social relations. Sixth, it is a means of securing a positive experience. Seventh, it is an effective means of socialization. Taking into account the aforementioned, we can confirm that social traditions are concentrate, and even a conglomerate of social values.

One of the possible ways of understanding a social tradition is a comparison of the recognized and described constructs. The tradition holds samples, forms of work organization, relationships, distribution, means and methods that have proven themselves in the past. Social traditions that make up the current value for the community, formed in the past and carry viable "old" maintaining stability while ensuring social positions. With regard to the origins of the formation of social innovation there are solutions that can change directly or indirectly selectively fixed social institutions in various sectors of the national economy. All interpretation, the meaning of which brings social innovations beyond improvement, development, change, transform them automatically into something else that is somewhere nearby and only.

\section{Innovation mechanism and foundation of social innovations}

The design of the innovation mechanism of social development shall be built on the fact that updating of the existing social traditions because of the changed social circumstances has a permanent character. Every next cycle of updating valuable components of the social tradition of regulation of the functioning processes of the society does not appear as separated from the previous one, and is in internal communication with it.

Development based on novation is oriented on the change of valuable content of the existing tradition, its transfer to a new quality. Novation, as a rule, appears and is implemented through modernization of the tradition. In case if it is recognized by the society, it is institutionalized.

Due to the fact that the practice on the innovation issues is ambiguous and the specialized literature on this fact has not offered final decision, let's find it appropriate to support the scientists who believe that the result of improvements of the existing traditions is novation, the components of which are interior and exterior novation

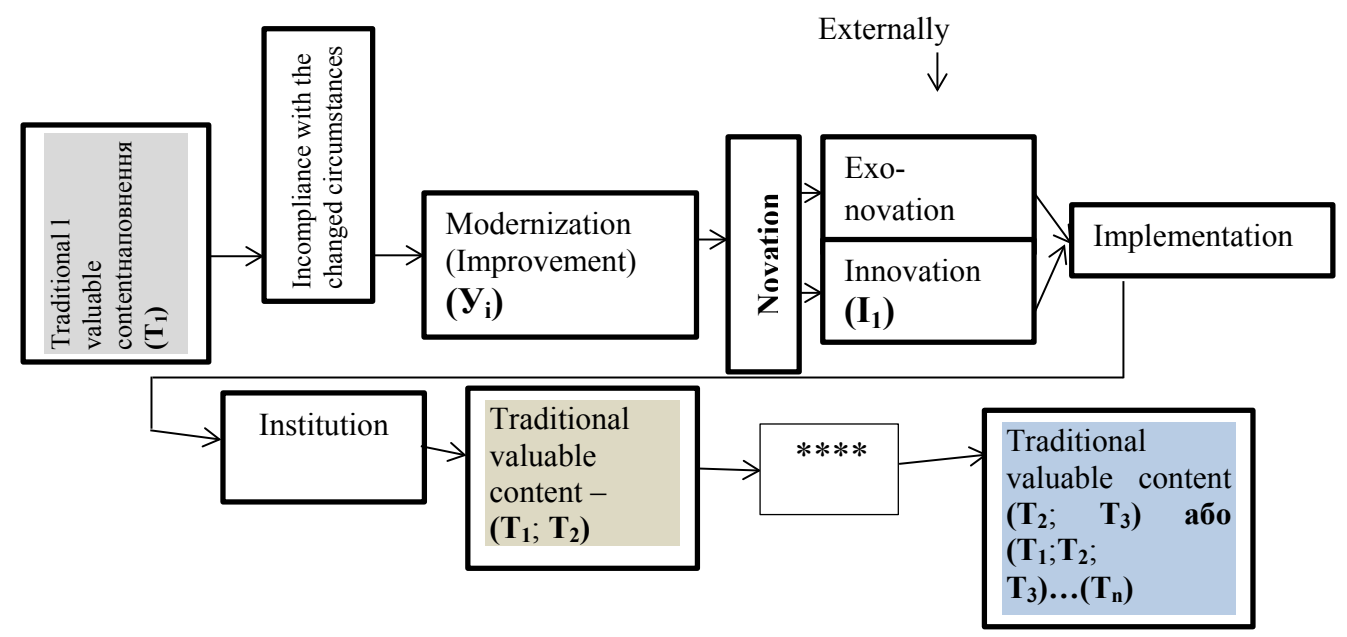

Fig. 1. Mechanism of cyclical renewal of institutional content of the Social Development regulation system 
constructs. In this case the novation decisions borrowed from outside according to the semantics of composite conceptual apparatus, in our opinion, should be called as exo-novation, and internal - innovation.

The foregoing gives an opportunity to give the scheme of universal mechanism of innovation of social development in the national economy (See Figure 1).

The scheme presented in Figure 1 shows that the fixation of the novation means the transition from the traditional system with its valuable content (T1) in a high-quality new state with valuable-formation system component ( $\mathrm{T} 1$, T2), which did not exist in the past. The past content of the public system establishment with tradition (T1) basically means providing it with a plurality of values, properties, characteristics and so that $T_{1}=f / x_{i}, y_{i}, z_{k}, l_{m}, n_{g}, \ldots . . /$. It is possible to assume only hypothetically that the whole set of values, properties; characteristics and so on shall be subject to changes. This change is actually made in relation to the limited number of $\mathrm{T}_{1}=\mathrm{f} / \mathrm{x}_{\mathrm{i}}, . . \mathrm{z}_{\mathrm{k}}, . . \mathrm{n}_{\mathrm{g}}, . . /$. If everything happened according to the different scenario and the system in all of their content would become the new characteristics, it would lose its continuity. The complete system change that is coming to the state $\left(\mathrm{T}_{2}\right)$ marks the end of the existing system and replaces it by another. "In this case, - emphasized P. Sorokin (2006) - we do not have the right to talk about the processes of changes, transformation, modification or evolution of the system, and only the replacement or displacement of the system (or process) to another, completely different from it can be talked about".

From the aforementioned it is clear that the new appear either on the foundation of the past and stipulated by it, or against it. From this follows the recognition that the emergence of entirely new unrelated to the past in any context is impossible. And when we are talking about something new, we mean exclusively qualitative characteristics. But it is not a blind adherence to it because doing so may cause certain difficulties or even block the way to the formation of innovation. Finally, always keep in mind that the transfer of the achievements of the past contemporaries solely because the tradition is to some extent absolutization of this process. There is a rational way to produce innovation through scientific and technical work. However, if you compare amounts in respect of purely scientific novation and novation stipulated by the traditions, the latter will surpass the first 9 times (Karmazina, 2014).

Quite clearly the potential of the chain "tradition novation” was described by M. Porter (1993, p. 64), emphasizing that "... most part of changes is evolutionary, not radical; accumulation of small changes often gives more than a major technological breakthrough ".

Thus, the tradition $\left(\mathbf{T}_{\mathbf{1}}\right)$, being the last in content, shall be reconstructed on the contemporary basis of today generally or in respect of certain values which makes not only partially reproduced $\left(\mathbf{T}_{1}\right)$, aut also updated $\left(\mathbf{T}_{2}\right)$. In this case the ontological sense the tradition $\left(\mathbf{T}_{1}\right)$ is not actually aimed at maintaining or mandatory change to $\left(\mathbf{T}_{2}\right)$. To the great extent it is something permanent in landmark changes (the first $-\mathbf{T}_{\mathbf{1}}=$ const, on the second $\mathbf{T}_{2}=$ const etc.). It can be compared to the foundation, which constantly forms something purely new or updated. The main purpose is to link the traditions of the past $\left(\mathrm{T}_{1}\right)$ to the future $\left(\mathbf{T}_{\mathbf{n}}\right)$ through modernity $\left(\mathbf{T}_{1}, \mathbf{T}_{2}\right)$.

In fact, following the description of the cycle novation updating of the economy, at first sight we can confirm its stereotype and structuring capabilities and algorithmic process of innovation. But this is an illusion. If the operation of technical systems has really stereotypes, the functioning of social systems is closely linked to the dynamics of other categories, namely development. Moreover, if the technical systems need accurate and unambiguous implementation of prescribed technology, social - after solving one problem, which brings to life a different and usually more complex, discover the means to solve it, and so on. It is natural that by virtue of the separated features the novation processes in the social dimension compared to the technical and technological sphere are implemented with a higher uncertainty about the consequences of their implementation and are characterized by difficulty in assessing the intended effect.

Guided by the tradition as social and civilization accumulated experience, it is by virtue of the speed of changes in the modern society is deformed and requires new orientation in life. In this sense tradition provides the necessary precondition for the implementation of creative processes, and innovation as their product becomes a potential source of new traditions. There is every reason to believe that the appointment of the tradition of the social plan is caused by setting a targeted vector of social dynamics by setting metamorphic aspect and stochasticity of a number of proposals to ensure innovation and thus the evolution of some persistent macro-states at the appropriate stage of social dynamics.

The fact that the relations between the terms "traditioninnovation" is more complex than it seems. Innovations with social overtones are made on the basis of improvement of component combinations of social traditions. In such a component range of social traditions a stream of improvements is quite diverse and in some ways not always focused. In this regard, there is a need to state that understanding of the social innovations requires their expansion by including para-social innovation and exonovation antisocial ones to them. Other authors also have the idea of isolating the innovations of negative or indifferent to ensure positive changes.

Thus, Yu. Yakovets (2004), providing classification of innovations, highlighted among them pseudo-innovation and anti-innovation. He referred those related to wrong ways of human ingenuity to the first ones, and to the second - those with reactionary nature and stipulating the reverse movement in any sphere of national economy. M. Huchek (1995) called innovation with such content as "simulated" and "unoriginal".

In our view, social and organizational innovation and institutional nature of non-compliance in providing social 
dynamics associated with dead-end management solutions and inadequate response to change. The prefix "para" [Greek para near, at $\mathrm{m}$ in the contrary, a deviation from somewhat or something "similar, but not identical"], which means deformation of the content designated with root part of the word "social" more accurately to reproduce the contents of "innovation" of the inhibitory nature. In the word "para-social" a prefix "para" give it a meaning of the antipode of social aspect in its traditional interpretation. Para-social aspect of social practice accumulates the total content of negative social issues.

Concerning the introduction of social innovations in practice the term "exo-novation anti-social", then it is about improvements imposed on the society, which is generally alien to the society. We shall distinguish formal and sometimes seeming innovations from those that really are such that bring to a qualitatively new level of social dynamics in a particular social space. Innovations that are frankly alien to the society represent a threat to the society and are able to even disrupt it.

In our opinion, adequate time would be appropriate to identify social innovation at the macro level with solutions that can change directly or indirectly selectively fixed institutions in various sectors of the national economy at the appropriate stage of socialization transformation with compulsory positivization of the social status of subjects of social and economic processes through constructs by mitigating revenue and income inequality.

\section{Research Methodology}

The methodological basis of the study is fundamental provisions of the economic theory of socialization of the market economy, the laws of dialectical logic and materialist understanding of social and historical development, the work of the leading foreign and domestic scientists, which highlights the problems of innovative development in general and social innovation in particular.

To solve this problem, a number of general scientific methods is used, such as analysis and synthesis during the critical evaluation of approaches of the domestic and foreign authors about the nature of "innovation", "novation" and "developments" of the systematic and structural in the design of the mechanism of the cyclicrenewal of institutional content of the regulation system of social development, summarizing the justification of the conceptual terminological apparatus including social innovation and gradual refinement of social innovation formulas, abstract logic when making theoretical generalizations and forming conclusions.

\section{Conclusions}

The survey results give an opportunity to confirm the presence of non-compliance of the theoretical constructs of social innovation with the changes of the reality according to the results of development of the oriented social market economy in the post-Soviet republics. The idea of the nature of "social" is not something that is not compounded, but does not get adequate time of formal nature. The concepts "innovation", "novation" and "developments" that dilute the content of the category "social innovation" are identified. The source base of social innovation that generates parasocial types of innovation and antisocial innovations has not been contoured until recently. It is difficult to rely not only on a theoretical breakthrough, but on the effective implementation of social innovation on the national territory without removing these destructions. The process of ordering and organizing the process of social innovation by certain rules and regulations will contribute, in our opinion, to the generation of forms of social integration and regulation of relations between individuals and their collective combinations relatively independent and also independent of individuals. And on the way of modernization of the mechanism of design and involvement of potential of social innovation can provide a number of contradictions about eliminating differences desired and actual conditions of social life that should be set to identify and distinguish the nucleus and spheres of influence.

\section{Conclusions of the scientific research}

The necessity of introducing the term "social" as normalized inequality in the society to the limits that defines the motivational aspects of work, and "innovation" as the changes that are generated within the social and economic system in the scientific use. It has been offered to interpret social innovation as solutions that can change directly or indirectly selectively fixed institutions in various sectors of the national economy at the appropriate stage of socialization transformation with compulsory positivization of the social status of subjects of social and economic processes through constructs of mitigating the revenue and income inequality. The falsity of orientation in the development of programs of social innovation on purely rational methods of production of innovation through scientific and technical work has been proved. It has been revealed that the new appears either on the foundation of the past and stipulated by it, or against it. From this follows the recognition that the emergence of entirely new unrelated to the past in any context is impossible. But by virtue of multi-purpose of definition of the social aspect there is a problem of setting a targeted vector of social dynamics by leveling stochasticity and metamorphic aspect of a number of novation proposals and thus ensuring the evolution of some persistent macrostates at the appropriate stage of social dynamics.

\section{References}

Andrushchenko, V.P., \& Mihalchenko M.I.(1996). Modern Social Philosophy. Course oflectures (2nd Ed., changed and amended). Kiev: Genesis.

Andrushchenko, V.P., \& Gorlach, N.I. (Ed). Sociology. Science of Society (1996).: Proc. Manual. Kharkov: Institute of Oriental Studies and International Relations; Rubicon. 
Azgaldov, G.G., \& Kostin, A.V. (2008). Intellectual property, innovation and qualimetry. Economic Strategies, 2 (60), 162-164. Cherepanova, N.V. (2007). Tradition and Innovation. Moskau: social humanitarian University.

Deeva, N.M. (2006). Potential of Socialization and its Regulation in the Economy: Theory, Methodology, Prospects. Dnipropetrovs'k: ART-PRESS.

Elias, N. (2001). On the Process of Civilization. Social-genetic and psychogenetic research. (in 2-V. T. 1.). Moskau Sanct-Peterburg: University Book.

Grishkin, V.O. (2005). Socialization of Economy of Ukraine: Theory, Methodology, Prospects. Dnipropetrovs'k: Porogi.

Huchek, M. (1995). Social and Economic content of innovation in the enterprise. Bulletin of Moscow University. Series 6 "Economy". 1.62-71.

Ozhegov, S.I. (Ed). (1953). Russian dictionary. Moskau: State Publishing House of foreign and national dictionaries. Ponomarev, B.N. (Ed). (1956). // Political Dictionary. Moskau: State Publishing House political literature.

Popper, K.R. (2004). Assumptions and denials: Growth of Scientific Knowledge . Moskau: Publishing House AST, LLC: CJSC NPP “Ermak”.

Perlaki, I. (1980). Innovations in Organizations. Moskau: Economics.

Prigogine, A.I. (1989). Innovations: Incentives and Disincentives. Moskau: Politizdat.

Porter, M. (1993). International Competition. Moskau: International Relations.

Karmazina, O. (Ed). Scientific and Innovation Activity in Ukraine (2014).: Statistical Collection. Kiev: State Statistics Service of Ukraine.

Schumpeter, J. (1982). Theory of Economic Development: Study of business Profits, Capital, Credit, Interest and Cycle Conditions. Moskau: Progress.

Sorokin, P.A. (2006). Social and Cultural Dynamics. Moskau: Astrel.

Yakovets, Yu. (2004). Epochal Innovations of the XXI century. Moskau.: Economics.

Yaremenko, V., \& Slipushko, O. (Ed). (2001). // Ne Interpretation vocabulary in the Ukrainian Language. (V.3) Kiev: Publishing House "Akonit".

Zinoviev, A.A. (2008). Logistic Sociology: Selected Writings. Moskau: Product.

\section{Ольга БИЛЬСКАЯ}

\section{ПРОИСХОЖДЕНИЕ ФОРМИРОВАНИЯ СОЦИАЛЬНЫХ ИННОВАЦИЙ В УСЛОВИЯХ ПЕРЕХОДНОЙ ЭКОНОМИКИ}

Аннотация. Целью работы является определение сущности, источником базы которой является механизм формирования "социальных инноваций" в условиях переходной экономики с рыночным механизмом для обеспечения деятельности на территории стран, которые осуществляют развитие социального государства. Методология. Для решения этой проблемы использовано ряд научных методов, таких как анализ и синтез во время критической оценки подходов отечественных и зарубежных авторов о природе "новация", “события" и "инновации", системно-структурный механизм циклического обновления содержания институциональной системы регулирования социального развития, подводя в обосновании концептуальных терминологический аппарат социальной инновации, и в частности постепенного прояснения формул социальных инноваций, делая абстрактно-логические теоретическое обобщение и выводы. Результаты исследования приводят к необходимости введения термина "социальное" в научном и практическом обороте, как нормализация неравенства в обществе до границ, которые определяют мотивационные аспекты работы, и “инновации” как изменения, которые генерируются в рамках социально-экономической системы. Предложено разъяснять социальные инновации, как решения, которые могут изменить напрямую или косвенно выборочно фиксированные учреждения в различных отраслях народного хозяйства страны на соответствующем этапе социализации преобразований с обязательной позивитацией социального статуса субъектов социальных и экономических процессов через конструкты смягчения доходов и неравенства в доходах. Доказано, что базовым источником социального инновирования являются социальные традиции, которые в силу многоцелевой определенности социального связаны с метаморфическими характеристика и стохастичностью набора предложений социальных инноваций и их деструктивных конструктов. Практическое значение. Организация понятийного и категориального аппарата социальных инноваций будет способствовать обоснованию социальной политики меры и исключит из практики урегулирования ситуации относительно непрофессионального решения проблемы обеспечения общественного прогресса. Значение/оригинальность. Научно-практическая значимость разработок означает, что они служат основой для теоретико-методологического обоснования процессов социальных инноваций, и должны меняться к лучшему благополучию населения. 